\title{
THE ECONOMICS OF EYESORES
}

\author{
John H. Cumberland and Leon Taylor*
}

\begin{abstract}
Few economic analyses exist of aesthetics regulation, an important tool for land-use planning. This paper uses simple geometry to calculate the Pareto-efficient height of an eyesore as well as its efficient distance from areas frequented by viewers. The paper provides a formula for a two-part Pigouvian tax to control eyesores as well as guidelines for its calculation. A tax is often more likely than conventional zoning instruments to enhance efficiency in the control of smoke plumes, signs, high-rises, and towers. As a more politically attractive alternative to the full compensation that eyesore laws mandate today, the paper recommends lump-sum compensation.
\end{abstract}

\section{INTRODUCTION}

Compared to other environmental issues, "eyesores"-man-made objects that vex viewers-have received little attention. The major U.S. law on eyesores is the Highway Beautification Act of 1965, which bans signs within 660 feet of the right-of-way of interstates and primary highways. The federal government was to pay 75 percent of the compensation to owners for the removal of their signs, but Congress never fully funded the program. Similarly, Congress did not specify a need to protect scenic views from plumes until the 1977 amendments to the Clean Air Act. Acting under those amendments, the Environmental Protection Agency required states to consider how plumes would affect major scenic views in national parks and wildemess areas. The states designated a handful of such "integral vistas" (Rodgers 1984).

This tolerance of eyesores is partly due to the perception that aesthetics matter less than the traditional environmental concerns of health and safety. Many early court decisions on billboard regulations echoed a New Jersey ruling that aesthetics were "a matter of luxury and indulgence"; only "necessity" could justify the removal of eyesores without compensation (City of Passaic 1905). Some state courts still maintain that aesthetic concem alone does not justify mandatory removal of eyesores. ${ }^{1}$

Several economic studies, however, suggest that aesthetic damages are important. ${ }^{2}$ Brookshire et al. (1976) estimated that vacationers at Lake Powell, on the Utah-Arizona border, would be willing to pay $\$ 700,000$ a year to prevent con-

\footnotetext{
*Professor Emeritus of Economics, University of Maryland System, Center for Environmental and Estuarine Studies, Chesapeake Biological Laboratory; and Assistant Professor of Economics, Tulane University, respectively. We thank the editors and referees of this joumal, as well as Alison Rose, for valuable comments.
} 
struction there of another unsightly power plant. This estimate is unlikely to be a wild pitch; several other studies have produced similar estimates of the willingness to pay for improved visibility in the Southwest (Rowe et al. 1980; Schulze et al. 1981).

One can infer from a variety of empirical studies that the income elasticity of the bid for aesthetic quality is positive but well below 1 . As per capita income increases, the public's distaste for eyesores will grow modestly. That distaste will sharpen if the supply of natural beauty continues to diminish, as some measures indicate. $^{3}$

The main problem facing policymakers in the control of eyesores is that aesthetic damages are subjective. For most viewers, visual intrusions are less likely to be disturbing in industrial parks than near pristine environments. But some visual intrusions, such as the Eiffel Tower, are initially regarded as eyesores and then later accepted as aesthetic triumphs. Indeed, some viewers might find beauty in manifestations of economic growth such as tanks and towers. The search for precise criteria by which courts can judge beauty "might well be abandoned because it does not make sense" (Dukeminier 1955).

But state courts typically permit removal of eyesores that sharply reduce the value of nearby properties (United Advertising 1964; Saveland 1955). This distinction between aesthetics and property value as a basis for regulation seems artificial: Property values reflect amenities and disamenities, so perhaps these values provide the measure of aesthetic damages that the courts seek. We might disagree on what aesthetic damages are-and yet agree that, whatever they are, they affect decisions to buy and sell locational rights. With that perspective, this paper develops a model for eyesore control through taxation of the owner. The analysis suggests relating the tax rate to the eyesore's height and to its proximity to areas frequented by viewers. ${ }^{4}$

In a world with no uncertainty and no transaction costs, height limits can achieve the same efficient outcome as taxes. But in a world more like our own, the tax enjoys several practical advantages. Most important is the traditional edge of pricing over planning: the tax-price requires less information from regulators. To impose height restrictions that are efficient, regulators must estimate the marginal damages imposed by eyesores and the marginal benefits of leaving them alone. To design a tax schedule, regulators need only estimate the marginal damages.

At present, before regulators can order the removal of an eyesore, they must often estimate its production value, either to amortize it or to compensate its owner. ${ }^{5}$ Many legal disputes tum on whether the regulator has valued the eyesore accurately. With a tax policy, the govemment need not try to value the eyesore. It is up to the eyesore owner to decide whether its value exceeds the tax bill. This 
feature of tax policy might make eyesore control more acceptable politically to the business community. ${ }^{6}$

In addition to a tax model, this paper develops a method for valuing the aesthetic benefits of air quality. Most studies have used contingent valuation to estimate the value of visibility (Rowe and Chestnut 1982). These estimates might overstate actual values, since respondents do not always perceive budget constraints. Policymakers could better gauge the value of aesthetics if they could also draw upon hedonic studies. But isolating aesthetic costs in hedonic studies of air pollutants is difficult. For instance, the student of particulate levels has trouble distinguishing the reduction in property values that is due to health risks from the reduction that is due to aesthetic damage (Niemeyer 1990). One might tackle this problem by studying haze, which threatens visibility rather than health. But air quality particularly affects property values within a region, not across regions. Haze levels vary too little within a region to relate to the variation in property values of that region. In sum, a hedonic study must focus on a pollutant that threatens aesthetics, rather than health, and that has a varying impact within a region. ${ }^{7}$ Our candidate is the eyesore.

Section II develops a two-tier tax designed to induce the landowner to select the Pareto-efficient location and height of the eyesore. Section III looks beyond efficiency to discuss the equity and political feasibility of regulating eyesores. Section IV concludes the paper with suggestions for future research.

\section{DESIGNING THE TAX}

A simple model will illustrate our approach. A firm has decided to build an eyesore at the center of a plain. It has yet to decide upon the eyesore's height, $h$. The taller the eyesore, the greater its production value, $V(h): d V / d h>0, d^{2} V / d h^{2}$ $<0$. The eyesore would impose social cost, $\mathrm{C}(\mathrm{h})$, by marring the site's natural beauty for viewers. These viewers might be residents or tourists; our analytical framework can handle either case. "Social cost" is the total amount that viewers, coming under the aesthetic shadow of the eyesore, would be willing to pay to eliminate it. Now we will characterize this equivalent surplus.

Let $\mathrm{t}$ be the eyesore's distance from a particular site. Let $\mathrm{v}$ be an index of visibility at the site. ${ }^{8}$ Let $\mathrm{e}$ be a vector representing other positive visual attributes of the site-for instance, the proximity of attractive vistas $(e \geq 0)$. Let $Z(t, h, v, e)$ be a function indexing the site's visual quality, where? 


$$
\begin{aligned}
& \frac{\partial Z}{\partial t}>0 \frac{\partial^{2} Z}{\partial t \partial t}<0 \\
& \frac{\partial Z}{\partial h}<0 \frac{\partial^{2} Z}{\partial h \partial h}>0 \\
& \frac{\partial Z}{\partial v}>0 \frac{\partial^{2} Z}{\partial \nu \partial \nu}<0 \\
& \frac{\partial Z}{\partial e}>0 \frac{\partial^{2} Z}{\partial e \partial e}<0 \\
& Z[t, 0, v, e]=\max Z[t, h, v, e] \\
& \min Z[t, h, v, e]=0
\end{aligned}
$$

Each viewer buys $\mathrm{X}$, a composite commodity. For a resident, $\mathrm{X}$ might include housing; for a tourist, $\mathrm{X}$ might include such travel commodities as food, lodging, and gasoline. The viewer's utility function is U[X,Z], where

$$
\begin{aligned}
& \frac{\partial U}{\partial X}>0 \frac{\partial^{2} U}{\partial X \partial X}<0, \\
& \frac{\partial U}{\partial Z}>0 \frac{\partial^{2} U}{\partial Z \partial Z}<0, \\
& \frac{\partial^{2} U}{\partial X \partial Z}=0 \quad \min U[X, Z]=0 .
\end{aligned}
$$

$P_{Z}$ is the shadow price of $Z$. The household selects $X, t, h, v, e$, and $\mu$ to solve

$$
\min X+P_{2} Z(t, h, v, e)+\mu\left[U(X, Z)-U^{0}\right]
$$

where $\mathrm{U}^{0}$ is the reservation level of utility. The first-order conditions imply that the viewer will buy site quality until its relative marginal value equals its relative price. $^{10}$

All viewers are perfectly mobile. In spatial equilibrium, all viewers must achieve $U^{0}$ in utility regardless of location. The expenditure function for each viewer is 


$$
E\left[P_{2}, U^{0}\right]=X\left[P_{z}, U^{0}\right]+P_{z} Z\left[t\left(P_{z}, U^{0}\right), h\left(P_{z}, U^{0}\right), v\left(P_{z}, U^{0}\right), e\left(P_{z}, U^{0}\right] .\right.
$$

Define the function

$$
K\left[t, h, v, e ; P_{2}, U^{0}\right] \equiv E\left[Z(t, 0, v, e) ; P_{2}, U^{0}\right]-E\left[Z(t, h, v, e) ; P_{2}, U^{0}\right] .
$$

$\mathrm{K}$ represents the maximum amount that a viewer would pay to bar construction of the eyesore. For an eyesore of given height, viewers near it would be willing to pay more to eliminate it than viewers farther away $(\mathrm{dK} / \mathrm{dt}<0)$. At a given distance, viewers would be willing to pay more to eliminate a tall eyesore than a short one $(\mathrm{dK} / \mathrm{dh}>0)$.

We wish to induce the eyesore owner to pick an efficient location as well as an efficient height. We will consider an eyesore to be built in a circular city, but the model extends to other settings.

The city populace thins out smoothly with distance $c_{0}$ from the central business district ( $\rho$ is population density; $d \rho / d c_{0}<0$ and $d^{2} \rho / d c_{0}^{2}>0$ ). ${ }^{11} \mathrm{~A}$ downtown location for an eyesore will disturb many residents, but it will also prove valuable by cutting transport costs $\left(\mathrm{dV} / \mathrm{dco}<0\right.$ and $\mathrm{d}^{2} \mathrm{~V} / \mathrm{dco}^{2}>0$; $\left.\mathrm{V}=\mathrm{V}\left(\mathrm{h}, \mathrm{c}_{0}\right)\right)^{12}$

Social cost depends on how many people view the eyesore and on how much they would pay to get rid of it. The eyesore is visible over a circle of radius $r$ encompassing $\rho \pi r^{2}$ viewers. The maximum distance over which an object of height $h$ (in feet) is visible is $1.317 \mathrm{~h}^{1 / 2}$ miles. At that point, the earth's curvature constrains visibility (Strahler 1975). The social cost of an eyesore to be built at distance $c 0$ and angle $\alpha$ from the CBD at height $h$ is ${ }^{13}$

$$
C[c 0, h ; \alpha]=\int_{0}^{2 \pi} \int_{0}^{1.317 h^{1 / 2}} t K[t, h] \rho[t, s ; c 0, \alpha] d t d s .
$$

Regulators can control the eyesore with a two-part tax. This tax is based upon the marginal social costs of proximity to downtown and of height, respectively:

$$
\begin{aligned}
& M S C_{c}=-\frac{\partial C}{\partial c 0}=-\int_{0}^{2 \pi} \int_{0}^{1.317 h^{h /}} t K[t, h] \frac{\partial \rho}{\partial c 0} d t d s, \\
& M S C_{h}=\frac{\partial C}{\partial h}=\int_{0}^{2 \pi} \int_{0}^{1.317 h^{h / 2}} t \rho \frac{\partial K}{\partial h} d t d s .
\end{aligned}
$$


Marginal social cost increases with height and population density. This implies, for instance, that as the seacoasts become more populated, the net social cost of eyesores will rise unless their productive value increases at the rate of population growth or greater. Marginal social costs also increase with proximity to downtown.

The owner picks the height and location that equate their respective values of marginal revenue product to the taxes, which are also their marginal social costs.

To estimate the tax on eyesores in residential areas, one can use this theoretical result: When labor is mobile and land markets work well, then construction of an eyesore will lower property values by $K[t, h, v, e]$. To calculate $K$, estimate by ordinary least squares a reduced form of (4):

$$
P V=f\left[Z(t, v, h, e), H_{1}, H_{2}, H_{3}, H_{4}, I\right]
$$

where PV is a measure of property value such as individual property sale price; $\mathrm{H}_{1}$ is a vector of the physical characteristics of the housing such as age, lot size, living area, and number of bathrooms; $\mathrm{H}_{2}$ is a vector of the socioeconomic characteristics of the neighborhood such as population density and percentage of residents who are African-American; $\mathrm{H}_{3}$ is a vector of taxes and publicly provided services to the neighborhood such as the property tax rate and the average test score of students at the neighborhood schools; $\mathrm{H}_{4}$ is a vector of other amenities and disamenities of the neighborhood such as the crime rate and the travel time to employment; and $I$ is a vector of variables influencing the shadow price $P_{Z}$ such as household income and number of years of education. With (9) in hand, use (5) to calculate K. Use (7) and (8) to calculate the two-tier tax. Similarly, one can estimate the tax on eyesores in recreational areas. ${ }^{14}$

For some eyesores, such as junkyards, the frontage -or configuration of land use-affects aesthetics more severely than height does. In the appendix, we investigate the configuration that minimizes the visual impact of an eyesore of a given area on a jurisdiction. We show that this configuration is the arc of a circle, beginning and ending on the outskirts of the jurisdiction. If the junkyard owner has a rectangular plot, then he should put the junkyard behind an arc cutting through the plot and set aside the front border areas for greenery. To induce the junkyard owner to reduce visual impact, the jurisdiction might levy a tax per foot of the actual frontage of the junkyard. 


\section{BEYOND EFFICIENCY}

Proposals to control visual intrusions raise compensation issues that vary with the form of control. The courts might interpret a ban on eyesores as a "taking" and require the government to compensate landowners. The courts are less likely to interpret an eyesore tax as a taking, since the landowner can choose to pay the tax and erect the eyesore. Even so, proposals to tax eyesores will arouse political opposition. If taxes replace strict zoning ordinances, then eyesores might enter some areas, angering viewers. ${ }^{15}$ If taxes replace a laissez-faire policy, then eyesores might diminish in some areas, angering eyesore owners. Compensation might reduce political opposition.

Suppose that government officials seek to determine the minimum amount of compensation required to dissuade an individual from undertaking rent-seeking opposition to a proposal. The officials might seek this goal in order to enhance efficiency, since rent-seeking might waste resources. Or officials might simply wish to forestall opposition so that they can pursue quiet lives. Let $\mathrm{C}$ represent resources consumed in rent-seeking opposition. Let $\mathrm{p}[\mathrm{C}]$ represent the probability that an individual can defeat a proposal by consuming $C$ resources: $d p / d C>0$, $d^{2} p / d C^{2}<0$. Let $L$ represent the loss anticipated by the individual from the program. Let $M$ represent compensation paid by the government to the individual. Paying full compensation would mean equating $M$ to $L$. Taking $C$ as given, govermment officials will select $M$ to satisfy

$$
L \geq M=p[C] L-C
$$

Knowing that rule, the individual will select $\mathrm{C}$ to maximize $\mathrm{M}$. Rearrangement of the first-order condition to that problem yields

$$
\frac{\partial p}{\partial C}=1 / L
$$

A choice of $C$ that satisfies (11) is sufficient to maximize $M^{16}$ It is straightforward to show that the individual will spend more on rent-seeking if he anticipates a larger loss or if he has greater political "pull" than other individuals.

If officials are well informed and seek only to forestall opposition, then they will not offer to fully compensate any individual. ${ }^{17}$ But laws and regulations goveming land use, such as the U.S. Highway Beautification Act, typically envision full compensation of owners for the removal of their eyesores. ${ }^{18}$ Perhaps officials prefer full compensation because, in a world of uncertainty, it provides an attractive rule of thumb. 
Full compensation, however, can distort decisions to relocate eyesores to less offensive sites. ${ }^{19}$ Suppose that owners A and B bid to relocate their billboards to an off-highway site with a gross value of $\$ 500$. For $A$, the cost of tearing down his highway billboard is $\$ 5,000$; for $B$, the cost is $\$ 501$. The off-highway site should go to B. But if A receives $\$ 5,000$ to remove his billboard, and B receives $\$ 501$, then both will bid $\$ 500$ for the new site. It might go to $A$.

In sum, when the costs of relocation differ among agents vying for sites, lump-sum compensation is more efficient for society-and cheaper for government-than full compensation. That govemment officials seem to prefer the latter in land-use regulation is a striking topic for future research.

Policymakers should also consider the impact of an eyesore tax upon the distribution of income. Many eyesores, such as strip mines, are resource or capital inputs that complement blue-collar labor. Regulating these eyesores can redistribute income away from the poor. ${ }^{20}$

Even so, an eyesore tax could have less drastic distributional consequences than the common alternative of banning eyesores in specified zones. Over time, as a residential area becomes wealthier or more populated, its demand for visual quality will rise, and so will its eyesore tax. But in most cases, the owner of an existing eyesore cannot choose to reduce it by a foot or two; he must either pay the tax or tear down the eyesore. He will pay until the tax claims all of the locational rent accruing to the eyesore. Thus, an eyesore might remain for several years. ${ }^{21}$ The government can put the tax revenues in a general fund, which makes possible compensatory payments or services to workers. In effect, the scheme offsets the reduction in income to workers by redistributing to them income from the factory's owners.

By contrast, conventional zoning might not reliably provide revenue by which the government can soften the impact upon workers. Banning eyesores will increase the value of residential properties but decrease the value of industrial properties and perhaps commercial properties. It is not clear that property tax revenues will increase.

In sum, the eyesore tax is more serviceable than zoning as a vehicle for redistribution of income, because it lays claim to a locational rent. Zoning changes relative locational rents, affecting not only redistribution but also allocation, perhaps in unintended ways.

\section{CONCLUSIONS}

The analysis fits a broad class of aesthetic intrusions into residential and vacation areas such as signs, towers, tanks, and antennas. The incentives that lead 
to locating such structures on the highest points of the landscape often conflict directly with the aesthetic goal of minimizing visual intrusions. Taxes on eyesores provide economic incentives for reducing welfare losses.

One can particularly apply the analysis to buildings located near such visual amenities as coasts, rivers, and lakes. A developer who seeks to maximize profits has reason to increase the height of the building: he can charge more rent for units that offer a sweeping view (Pollard 1982). But increasing the height of the building blocks the view of those who do not live in the building.

That extemality might not lead to significant failure in a real estate market of only a few developers. The developers whose rents would suffer from an occluded view could bargain with the developer of the building nearest the amenity (Coase 1960). But if the market includes many agents-for instance, owners of single-family homes-then a height tax might resolve the problem at a lower resource cost than bargaining.

The visibility literature has influenced environmental economics profoundly by developing and testing rigorous methods of valuation. ${ }^{22}$ To this literature, we hope to contribute a spatial analysis. Analysts might categorize visual impairments by the degree of their diffusion over space. A plume of nitrogen dioxide, rising from a power plant on a windless day, does not affect viewers the same way as a haze of nitrogen dioxide, although the total volume of the pollutant might be the same in both cases. The haze equally inconveniences all viewers who are under it. But the plume disturbs viewers who are close to it more than viewers who are far away. The less diffuse the impairment, the more important that distance becomes. Although our analysis focuses on eyesores, one can extend it to a visual impairment with any degree of diffusion.

Of the research issues that remain, the determinants of existence value are particularly important. This value, which people attach to knowing that a scenic area exists, appears large for such national treasures as the Grand Canyon (Schulze et al. 1981). In such cases, an eyesore ban might work better than a tax that reflects only user value.

\section{APPENDIX}

We will derive the configuration that minimizes the impact of an obnoxious facility of given area A. The treatment follows Kamien and Schwartz (1981). Consider a circular city, centered on point $(r, 0)$ in the $t-Y$ plane. The city border is

$$
\begin{aligned}
& Y(t)=\sqrt{r^{2}-(t-r)^{2}}, \\
& t \leq 2 r .
\end{aligned}
$$


To minimize impact, the facility border that faces the city should begin and end on the city border. Call this facility border $\mathrm{X}(\mathrm{t})$. For simplicity, suppose that one endpoint is the origin $(0,0)$; the model is easily generalized to an arbitrary endpoint on the city border. The other endpoint is $\left[\mathrm{t}_{1}, \mathrm{X}\left(\mathrm{t}_{1}\right)\right]$, to be selected subject to the constraint

$$
r^{2}=\left(t_{1}-r\right)^{2}+X\left(t_{1}\right)^{2}
$$

The length of $X(t)$ is

$$
\int_{0}^{t_{1}} \sqrt{1+\frac{d x^{2}}{d t}} d t
$$

We will pick $X(t)$ and $t_{1}$ to minimize

$$
\left.\int_{0}^{t_{1}} \sqrt{1+\frac{d X^{2}}{d t} d t}+\mu\left[\int_{0}^{t_{1}} \sqrt{r^{2}-(t-r)^{2}}-X(t) d t-A\right\}\right]
$$

The constraint ensures that the facility boundary is sufficient to border an area of size A.

Any solution to (A.4) must satisfy the Euler equation

$$
-\lambda=\frac{d}{d t} \frac{\frac{d X}{d t}}{\sqrt{1+\frac{d X^{2}}{d t}}}
$$

One can rewrite an Euler equation as a second-order differential equation. In this case, we can solve (A.5) for $\mathrm{X}(\mathrm{t})$ directly by twice integrating both sides of (A.5). The first integration yields

$$
k-\lambda t=\frac{\frac{d X}{d t}}{\sqrt{1+\frac{d X^{2}}{d t}}}
$$

where $\mathbf{k}$ is a constant. Preparing for the second integration requires several manipulations. First, square both sides of (A.6) and obtain a simpler expression for $\mathrm{dX} / \mathrm{dt}$ : 


$$
\begin{aligned}
& \frac{1}{(k-\lambda t)^{2}}=\frac{1+\frac{d X^{2}}{d t}}{\frac{d X^{2}}{d t}}=\frac{1}{\frac{d X^{2}}{d t}}+1 \\
& \frac{(k-\lambda t)^{2}}{1-(k-\lambda t)^{2}}=\frac{d X^{2}}{d t} .
\end{aligned}
$$

Take the square root of both sides, separate variables, and integrate:

$$
\int d x=\int \frac{k-\lambda t}{\sqrt{1-(k-\lambda t)^{2}}} d t
$$

Solve the right-hand integral with the substitution $u=1-(k-\lambda t)^{2}$. Obtain

$$
X(t)-c=\frac{\sqrt{1-(k-\lambda t)^{2}}}{\lambda}
$$

where $\mathrm{c}$ is a constant. Square both sides and rearrange:

$$
(t-m)^{2}+(X-c)^{2}=(1 / \lambda)^{2}
$$

where $m=s / \lambda$ and $s$ is a constant. The best internal border for the facility is the arc of a circle with radius $1 / \lambda$ and center $(m, c){ }^{23}$

The optimal internal border for the facility must satisfy (A.11) for all $t$ in $\left[0, t_{1}\right]$. We are free to pick $t_{1}$, however, subject to the constraint that it satisfies (A.2). To express the transversality condition, a bit of notation will ease the way: Denote $\mathrm{dX} / \mathrm{dt}$ as $\mathbf{X}^{\prime}$. Denote (A.3) as the function $\mathbf{F}\left(\mathbf{X}^{\prime}\right)$. Denote $\mathbf{X}\left(\mathrm{t}_{1}\right)$ as $\mathbf{X}_{1}$. Finally, rewrite (A.2) as the implicit function

$$
Q\left(t_{1}, X_{1}\right)=X_{1}^{2}+\left(t_{1}-r\right)^{2}-r^{2}
$$

where $\mathrm{X}_{1}$ and $\mathrm{t}_{1}$ are to be treated as independent variables.

The transversality condition is that, at $\mathrm{t}=\mathrm{t}_{1}$,

$$
F\left(X^{\prime}\right)-\frac{d F}{d X^{\prime}}\left[X^{\prime}+\frac{\frac{d Q}{d t}}{\frac{d Q}{d X}}\right]=0
$$


Appropriate substitutions into (A.13) yield

$$
\sqrt{1+X^{\prime 2}}-\frac{X^{\prime}}{\sqrt{1+X^{\prime 2}}}\left[X^{\prime}+\frac{t_{1}-r}{X_{1}}\right]=0
$$

Multiply through (A.14) by $\left(1+\mathrm{X}^{\prime 2}\right)^{1 / 2}$. Simplify and rearrange:

$$
X^{\prime}=\frac{X_{1}}{t_{1}-r}
$$

At the optimal endpoint, the facility's terminal boundary is perpendicular to the city's boundary.

\section{ENDNOTES}

1. An Arizona opinion held that "public interest in aesthetics, standing alone, is often too vague to offset substantial injury to a landowner in a rezoning case" (Corrigan 1986). An Ohio opinion noted that "aesthetic conditions alone are insufficient to support the invocation of the police power ..." (Reid 1963).

2. Even if an individual would pay little to eliminate an eyesore, the aggregate willingness of viewers to pay can be large, since eyesores are potentially sweeping in visibility. In the Rocky Mountain states, annual median visual range exceeds 100 miles.

We can illustrate the sweep of an eyesore on the East Coast. In the mid1980s, two natural gas companies mothballed their LNG terminal on the largely undeveloped mid-westem shore of the Chesapeake Bay. But its unloading armsrising 118 feet above sea level a mile off the shore-remained visible from more than 14 miles away. Most boaters do not come to these waters to see a feat of engineering. They come for recreation and for a view of "that noble arm of the sea." The eyesores dissuade some from returning. Our back-of-the-envelope calculations suggest that the unloading arms reduce the income that Maryland receives from recreational boating by more than $\$ 400,000$ a year. (Calculations are available on request from the authors.)

3. While there seems to be no systematic study of time trends in the supply of natural beauty, some statistics are suggestive. Since 1700, the earth has lost six million square kilometers of forest, an area larger than Europe (Clark 1989). In the United States, data from the National Weather Service indicate that summer visibility over much of the eastem United States has decreased 50 percent since 1948 (U.S. House of Representatives 1985, 542). 
4. One legal precedent for an eyesore tax is a city fee on signs. In Veterans (1978), a Colorado court sustained a sign code including a fee.

5. "Whatever may be the law with respect to zoning restrictions based upon aesthetic considerations," said a Wisconsin opinion, "a stronger argument can be made in support of the power to take property, in return for just compensation, in order to fulfill aesthetic concepts, than for the imposition of police power restrictions for such purposes" (Kamrowski 1966).

6. One might ask why regulators should use taxes to control eyesores rather than transferable development permits. Like taxes, transferable permits discourage the construction of those eyesores that impose the greatest net social costs. In addition, courts and agencies in the United States are more familiar with permits than with Pigouvian taxes.

We believe that research into eyesore control policies should focus first on taxes. The determination of the efficient number of permits to issue requires more information than the construction of an efficient tax schedule. Also, the cost of misestimating the number of permits to issue is probably greater than the cost of misestimating the tax schedule. Our sense is that the marginal cost of reducing eyesores rises more steeply than the marginal cost of leaving them alone. Setting the tax too low incurs smaller costs than setting the number of permits too low, assuming the same margin of error in either case (Baumol and Oates 1988).

Critics often argue that pollution taxes are harder to monitor and enforce than standards requiring capital installation. The argument does not apply to eyesore taxes. A factory cannot disguise the fact that its smokestack is 200 feet high and is 9 miles north of downtown. In this light, eyesore taxes might provide an ideal test of economic incentives.

7. An altemative is to study the impact of scenery on property values (Abelson 1979).

8. In particular, $v$ is the maximum distance at which an observer at the site can discem an object-of given size, detail, and color-that is along the ray that connects the site and the eyesore and that is at the same altitude as the site. For $\mathrm{v}$, one might use meteorological range-the distance at which the contrast of a large black object to the ideal horizon is no more than 2 percent (Rowe and Chestnut 1982).

9. $\mathrm{Z}$ is continuous and differentiable for all non-negative values of its arguments. All first and second partials of $Z$ are continuous. For simplicity, we set all cross-partials of $\mathrm{Z}$ to zero.

Visibility researchers compute a "visual air quality index" from a survey in which observers rank the quality of a scenic view on a scale ranging from 1 to 10 (Rowe and Chestnut 1982). We try here to provide a theoretical framework for such computations. 
10. A necessary condition for optimization is that

$$
\frac{\frac{\partial U}{\partial Z}}{\frac{\partial U}{\partial X}}=P_{Z}
$$

11. We need not make that assumption about the density gradient. But it is consistent with much of the urban economics literature, and it seems sensible (Mills 1969). If locations near the CBD enable users to reduce transportation costs, then land prices will rise accordingly. Users will economize by increasing the density of land use.

12. The value of height is independent of the value of location: $\mathrm{dV} / \mathrm{dcodh}=0$.

13. A special case is an eyesore onshore, casting an aesthetic shadow over a half-circle of residences. Social costs would be half of those given by (6).

14. The reduced form of (5) might use expenditures per tourist day as the proxy for $\mathrm{E}$.

15. Property owners often fear that eyesores will reduce property values. In Montgomery County, Maryland, a classical music station angered residents of Germantown by seeking a zoning exception to build four 406-foot radio towers in the midst of their community (Schwennesen 1989).

16. The second-order condition is

$$
\frac{\partial^{2} p}{\partial C^{2}} L<0
$$

17. If $C$ is positive, then equating $M$ to $L$ implies that $p[C]$ exceeds 1 .

18. Under Title I of the Highway Beautification Act, a state could lose 10 percent of its federal highway aid if it failed to pay "just compensation" for removing billboards that had been erected legally along interstates and primary highways. The federal government would pay 75 percent of the compensation; the state would pay 25 percent. Most state laws complying with the Highway Beautification Act also require "just compensation" (Mandelker and Cunningham 1979).

19. Building on work by Martin J. Bailey, Baumol and Oates (1988) analyze the effects of full compensation on locational decisions.

20. Consider surface mining in the area of Monongahela National Forest in West Virginia. Households earning less than $\$ 25,000$ a year would receive twothirds of the mining income (Rose et al. 1988). 
21. Compare this scheme to amortization, under which the jurisdiction lets the eyesore remain for a time without taxing its presence or compensating for its eventual removal.

22. One of the first visibility studies, Randall et al. (1974), won an award in 1992 as a Publication of Enduring Quality from the Association of Environmental and Resource Economists.

23. One can solve for the five values $m, c, \lambda, t_{1}$ and $X\left(t_{1}\right)$ from the constraints and the necessary conditions for optimization. Use (A.2); the constraint on facility area that is given by the bracketed expression in (A.4); the initial condition $X(0)=0$; the terminal constraint $X\left(t_{1}\right)=X_{1}$; and (A.15) with substitutions from (A.11).

\section{REFERENCES}

Abelson, Peter W. "Property Prices and the Value of Amenities." Journal of Environmental Economics and Management 6 (1979): 11-28.

Baumol, William J., and Wallace E. Oates. The Theory of Environmental Policy. 2d ed. Cambridge, Mass.: Cambridge University Press, 1988.

Brookshire, David S., Berry C. Ives, and William D. Schulze. "The Valuation of Aesthetic Preferences." Journal of Environmental Economics and Management 3 (1976): 325-346.

"City of Passaic v. Paterson Bill Posting, Advertising and Sign Painting Co." Atlantic Reporter 62 (1905): 267-269.

Clark, William C. "Managing Planet Earth." Scientific American 261 (1989): 4654.

Coase, Ronald H. "The Problem of Social Cost." The Journal of Law and Economics 3 (1960): 1-44.

"Corrigan v. City of Scottsdale." Pacific Reporter, 2d series. 720 (1986): 528-540.

Dukeminier, J. J., Jr. "Zoning for Aesthetic Objectives: A Reappraisal." Law and Contemporary Problems 20 (1955): 218-237.

Kamien, Morton I., and Nancy L. Schwartz. Dynamic Optimization: The Calculus of Variations and Optimal Control in Economics and Management. New York: North-Holland, 1981.

"Kamrowski v. State." North Western Reporter, 2 d series. 142 (1966): 793-798.

Mandelker, Daniel R., and Roger A. Cunningham. Planning and Control of Land Development: Cases and Materials. Indianapolis: The Bobbs-Merrill Co., 1979.

Mills, Edwin S. "The Value of Urban Land." In The Quality of the Urban Environment, edited by Harvey S. Perloff, 231-253. Washington, D.C.: Resources for the Future, 1969. 
Niemeyer, Victor. "Measuring the Value of Improved Visibility." EPRI Journal 15 (1990): 50-53.

Pollard, Robert. "View Amenities, Building Heights, and Housing Supply." In The Economics of Urban Amenities, edited by Douglas B. Diamond, Jr. and George S. Tolley, 105-124. New York: Academic Press, 1982.

Randall, Alan, Berry Ives, and Clyde Eastman. "Bidding Games for Valuation of Aesthetic Environmental Improvements." Journal of Environmental Economics and Management 1 (1974): 132-149.

"Reid v. Architectural Board of Review." North Eastern Reporter, 2d series. 192 (1963): 74-81.

Rodgers, William H., Jr. Handbook on Environmental Law: 1984 Pocket Part. St. Paul, Minn.: West Publishing Co., 1984.

Rose, Adam, Brandt Stevens, and Gregg Davis. Natural Resource Policy and Income Distribution. Baltimore, Md.: The Johns Hopkins University Press, 1988.

Rowe, Robert D., Ralph C. d'Arge, and David S. Brookshire. "An Experiment on the Economic Value of Visibility." Journal of Environmental Economics and Management 7 (1980): 1-19.

Rowe, Robert D., and Lauraine G. Chestnut. The Value of Visibility: Theory and Application. Cambridge, Mass.: Abt Books, 1982.

"Saveland Park Holding Corp. vs. Wieland." North Western Reporter, 2d series. 69 (1955): 217-224.

Schulze, William D., Ralph C. d'Arge, and David S. Brookshire. "Valuing Environmental Commodities: Some Recent Experiments." Land Economics 57 (1981): 151-72.

Schwennesen, J. L. "How Can 400-Foot Radio Towers 'Blend In' With Our Neighborhood?" Washington Post, 27 August 1989, p. C8.

Strahler, Arthur Newell. Physical Geography. 4th ed. New York: Wiley, 1975.

"United Advertising Corp. v. Metuchen." Atlantic Reporter, 2d series. 198 (1964): 447-454.

U.S. House of Representatives, Committee on Interior and Insular Affairs, Subcommittee on National Parks and Recreation. Hearings on Impacts of Air Pollution on National Park Units. Washington, D.C.: 99th Congress, 1st session, 1985.

"Veterans of Foreign Wars, etc. v. Steamboat Springs." Pacific Reporter, 2d series. 575 (1978): 835-843. 